\section{REFERENCES AND NOTES}

1. Arata, J., Umemura, S., Yamamoto, Y., Hagiyama, M., and Nohara, N. Prolidase deficiency. Its dermatological manifestations and some additional biochemical studies. Arch. Dermatol., 115: 62 (1979).

2. Bird, E. D.: Chemical pathology of Huntington's disease. Ann. Rev. Pharmacol Toxicol., 20: 533 (1980).

3. Buist, N. R. M., Strandholm, J. J., Bellinger, J. F., and Kennaway, N. G Further studies on a patient with iminodipeptiduria: a probable case of prolidase deficiency. Metabolism, 21: 1113 (1972).

4. Chan, W-Y., Cushing, W., Coffman, M. A., and Rennert, O. M.: Genetic expression of Wilson's disease in cell culture: a diagnostic marker. Science, 208: 299 (1980).

5. Charpentier, C., Dagbovie, K., Lemmonier, A., Larregue, M., and Johnstone R. A. W.: Prolidase deficiency with iminodipeptiduria: biochemical investigations and first results of attempted therapy. J. Inher. Metab. Dis., 4: 77 (1981).

6. DerKaloustian, V. M., Freij, B. J., and Kurban, A. K.: Prolidase deficiency: an inborn error of metabolism with major dermatological manifestations. Dermatologica, 164: 293 (1982).

7. Efron, M. L., Young, D., Moser, H. W., and MacCready, R. A.: A simple chromatographic screening test for the detection of disorders of amino acid metabolism. N. Engl. J. Med., 270: 1378 (1964).

8. Endo, F. and Matsuda, I.: Screening method for prolidase deficiency. Hum. Genet., 56: 349 (1981)

9. Endo, F., Matsuda, I.; Ogata, A., and Tanaka, S.: Human erythrocyte prolidase and prolidase deficiency. Pediatr. Res., 16: 227 (1982).

10. Goodman, S. I., Solomons, C. C., Muschenheim, F., Mclntyre, C. A., Miles, B., and O'Brien, D.: A syndrome resembling lathyrism associated with iminodipeptiduria. Amer. J. Med., 45: 152 (1968).

11. Isemura, M., Hanyu, T., Gejyo, F., Nakazawa, R., Igarashi, R., Matsuo, S. Ikeda, K., and Sato, Y.: Prolidase deficiency with iminodipeptiduria. A familial case with and without clinical symptoms. Clin. Chim. Acta, 93:401 (1979).

12. Kaufman, S.: Phenylketonuria. Biochemical mechanisms. Adv. Neurochem 2: 1 (1976).

13. Levy, H. L.: Genetic screening. Adv. Hum. Genet., 4: 1 (1973)

14. Levy, H. L., Coulombe, J. T., and Shih, V. E.: Newborn urine screening. In:
H. Bickel, R. Guthrie, G. Hammersen: Neonatal Screening for Inborn Errors of Metabolism. p. 89-103 (Springer-Verlag, Heidelberg, 1980).

15. Powell, G. F., Kurosky, A., and Maniscalco, R. M.: Prolidase deficiency: report of a second case with quantitation of the excessively excreted amino acids. J. Pediatr., 9J: 242 (1977).

16. Powell, G. F., Rasco, M. A., and Maniscalco, R. M.: A prolidase deficiency in man with iminopeptiduria. Metabolism, 23: 505 (1974).

17. Pyeritz, R. E. and McKusick, V. A.: The Marfan syndrome: diagnosis and management. N. Engl. J. Med., 300: 772 (1979).

18. Rej, R. and Richards, A. H.: Interference by tris buffer in the estimation of protein by the Lowry procedure. Anal. Biochem., 62: 240 (1974).

19. Rosenberg, M. and Court, D.: Regulatory sequences involved in the promotion and termination of RNA transcription. Ann. Rev. Genet., 13: 319 (1979).

20. Scriver, C. R. and Clow, C. L.: Phenylketonuria: epitome of human biochemical genetics. N. Engl. J. Med., 303: 1336 (1980).

21. Sheffield, L. J., Schlesinger, P., Faull, K., Halpern, B. J., Schier, G. M., Cotton, R. G. H., Hammond, J., and Danks, D. M.: Iminopeptiduria, skin ulcerations, and edema in a boy with prolidase deficiency. J. Pediatr., 91: 578 (1977).

22. Spackman, D. H, Stein, W. H., and Moore, S. Automatic recording apparatus for use in the chromatography of amino acids. Anal. Chem., 30:1190 (1958).

23. This work was presented at the 1982 meeting of the Society for Pediatric Research in Washington, D.C. and published as an abstract in Pediatr. Res. 16: 333A (1982)

24. The present address of Eileen R. Naughten is: Children's Hospital, Temple Street, Dublin, Ireland.

25. The present address of Susan P. Proctor is: Department of Nutrition Tuft University, Somerville, Massachusetts

26. The authors wish to thank Victor Nikiforov for his technical assistance and May Vuilleumier for her aid in the preparation of this manuscript.

27. Requests for reprints should be addressed to: Dr. Harvey L. Levy, Amino Acid Laboratory, Massachusetts General Hospital, Boston, MA 02114 (USA).

28. Supported by grant NS 05096 from the National Institute of Neurological and Communicative Disorders and Stroke and by project grant 01-H-000111 from the Bureau of Health Care, Delivery and Assistance, U.S. Department of HHS.

29. Received for publication December 14, 1982.

30. Accepted for publication May 20, 1983.

\title{
Effect of Different Total Parenteral Nutrition Fuel Mixes on the Body Composition of Infant Miniature Pigs
}

\author{
R. J. SHULMAN, ${ }^{(37)}$ M. L. FIOROTTO, H.-P. SHENG, AND C. GARZA \\ USDA/ARS Children's Nutrition Research Center, Department of Pediatrics, Baylor College of Medicine, Texas \\ Children's Hospital, Houston, Texas, USA
}

\section{Summary}

At $10 \mathrm{~d}$ of age miniature pigs were randomized to receive either of two total parenteral nutrition fuel mixes; oral feedings were discontinued. Both groups received $170 \mathrm{kcal} \cdot \mathrm{kg}^{-1} \cdot \mathrm{d}^{-1}$ and $11 \mathrm{~g}$. $\mathrm{kg}^{-1} \cdot \mathrm{d}^{-1}$ of synthetic amino acids. Nonprotein energy was supplied as glucose in group $A$, whereas in group B, it was divided equally between glucose and fat. Blood samples were drawn on the second and eighth postoperative days for hematologic, biochemical, and hormonal measurements. On the ninth postoperative day, total body water was determined and the animals were killed for carcass analysis. The animals tolerated the intravenous nutrition without ill effects as indicated by both clinical and biochemical parameters. Group A had significantly elevated levels of insulin and a higher insulin/glucagon ratio than group
B. Cortisol levels did not differ significantly between groups. Total body fat, nitrogen, ash, $\mathrm{K}, \mathrm{Na}, \mathrm{Cl}, \mathrm{Ca}$, and $\mathrm{P}$ were similar between groups. TBW was significantly greater in group $\mathbf{A}$ compared with group B. Extracellular space calculated from body $\mathrm{Cl}$ and plasma $\mathrm{Cl}$ was similar between groups.

\section{Abbreviations}

CBC, complete blood count

TBW, total body water

TPN, total parenteral nutrition

TPN is a life saving means of nutritional support for patients who are unable to absorb adequate amounts of nutrients. The 
energy (fuel mix) and nitrogen sources used in TPN usually consist of glucose and synthetic amino acids (21). Recently, fat has been advocated as an additional source of energy (30). Infants and children may be maintained on long-term TPN during periods of rapid growth, but little attention has been given to the consequences of the use of different fuel mixes on the composition of growth.

Certain metabolic effects might be anticipated as a result of the different hormonal profiles engendered by different fuel mixes. Such metabolic alterations may influence body composition and growth. A fuel mix of glucose and amino acids will stimulate a larger increase in plasma insulin and decrease the secretion of glucagon when compared with the effects of a fuel mix which includes glucose, amino acids, and fat (17). The hormonal profile seen with the latter fuel mix more closely resembles that observed during oral feedings (1). Although net nitrogen retention does not seem to be affected by the intravenous energy source $(4,14)$, studies using indirect methods to assess body composition in malnourished adults suggest that a glucose/amino acid fuel mix increases body water and fat disproportionately to the quantities expected from the amount of nitrogen retained (22). In contrast, a glucose/amino acid/fat fuel mix appears to lead to more balanced increases in body water, fat, and nitrogen (22).

The possible effects on body composition induced by these hormonal responses have not been investigated thoroughly in the growing individual maintained on TPN. In order to study the effect of the TPN fuel mix in the young infant, a model was developed using the infant miniature pig, an animal whose body composition closely resembles that of the human infant (27).

\section{MATERIALS AND METHODS}

Design. Pitman-Moore/Hanford strain minipigs (Bastrop Farms, Bastrop, TX) were weaned at $3 \mathrm{~d}$ of age and transported to our laboratory. The piglets were housed in separate cages in a room with an ambient temperature of $28^{\circ} \mathrm{C}$. The animals were weighed daily for the duration of the experiment. At $10 \mathrm{~d}$ of age the animals underwent surgical placement of central venous catheters and subsequently were randomized to receive either of two TPN fuel mixes; oral feedings were discontinued. On the second and eighth postoperative days, between $7: 45$ and $8: 15$ AM, blood samples for hematologic, biochemical, and hormonal measurements were withdrawn through the central venous catheters without disturbing the pigs. A urine sample was checked daily for the presence of glucose, ketones, blood, and protein. On the ninth postoperative day TBW was determined and the animals were then killed for carcass analysis.

Diet. The pigs were fed an artificial milk formula (Soweena, Foremost Foods, San Francisco, CA) ad libitum from the time they were weaned until surgery. Over the first $24 \mathrm{~h}$ postoperatively, the animals received solutions which contained half the concentrations of glucose and amino acids shown in Table 1. Group A received $157 \mathrm{ml} \cdot \mathrm{kg}^{-1} \cdot \mathrm{d}^{-1}$ and group B received 120 $\mathrm{ml} \cdot \mathrm{kg}^{-1} \cdot \mathrm{d}^{-1}$ of the glucose/amino acid solution in addition to $15 \mathrm{ml} \cdot \mathrm{kg}^{-1} \cdot \mathrm{d}^{-1}$ of intravenous fat emulsion (Intralipid $20 \%$, Cutter Medical, Berkeley, CA); thus, pigs in both groups received $72 \mathrm{kcal} / \mathrm{kg}$ over the first $24 \mathrm{~h}$. On the day after surgery (the first postoperative day), full strength (Table 1) glucose and amino acid concentrations were administered and the rates of infusion were increased to $185 \mathrm{ml} \cdot \mathrm{kg}^{-1} \cdot \mathrm{d}^{-1}$ for group $A$ and $153.5 \mathrm{ml}$. $\mathrm{kg}^{-1} \cdot \mathrm{d}^{-1}$ for group B in addition to $31.5 \mathrm{ml} \cdot \mathrm{kg}^{-1} \cdot \mathrm{d}^{-1}$ Intralipid. Both groups thus received $170 \mathrm{kcal} \cdot \mathrm{kg}^{-1} \cdot \mathrm{d}^{-1}$ and $11 \mathrm{~g} \cdot \mathrm{kg}^{-1} \cdot \mathrm{d}^{-1}$ of synthetic amino acids (Travasol, Travenol Laboratories, Deerfield, IL) for the duration of the study. In group B, nonprotein energy was divided equally between glucose and fat. Equal amount of minerals and vitamins appropriate for pigs were supplied to both groups $(25,27)$.

Surgical procedures. On the day of surgery the animals were anesthetized with ketamine $(20 \mathrm{mg} / \mathrm{kg}$ intramuscularly) followed
Table 1. Composition of the fuel mixes (per liter)

\begin{tabular}{lcc}
\hline & Group A & Group B \\
\hline Amino acids $(\mathrm{g})$ & 59.5 & 71.7 \\
Glucose $(\mathrm{g})$ & 200 & 121.0 \\
$\mathrm{NaCl}(\mathrm{mmol})$ & 16.2 & 19.4 \\
$\mathrm{KCl}(\mathrm{mmol})$ & 13.7 & 16.2 \\
$\mathrm{~K}_{2} \mathrm{HPO}_{4}(\mathrm{mmol})$ & 5.41 & 6.6 \\
$\mathrm{Ca}$ gluconate $(\mathrm{mmol})$ & 4.05 & 4.97 \\
$\mathrm{MgSO}_{4}(\mathrm{mmol})$ & 4.6 & 5.52 \\
$\mathrm{MVl}-12^{*}(\mathrm{ml})$ & 1.84 & 2.18 \\
$\mathrm{Zn}(\mathrm{mg})$ & 5.34 & 6.5 \\
$\mathrm{Cu}(\mathrm{mg})$ & 0.33 & 0.4 \\
$\mathrm{Mn}(\mathrm{mg})$ & 0.22 & 0.26 \\
$\mathrm{Se}(\mu \mathrm{g})$ & 8.6 & 10.4 \\
$\mathrm{I}(\mu \mathrm{g})$ & 8.6 & 10.4 \\
$\mathrm{H}{ }_{2} \mathrm{O}(\mathrm{ml})$ & 78.75 & 60.98 \\
& & \\
$\mathrm{Volume}\left(\mathrm{ml} \cdot \mathrm{kg}^{-1} \cdot \mathrm{d}^{-1}\right)$ & 185 & 153.5 \\
$20 \%$ Intralipid $\left(\mathrm{ml} \cdot \mathrm{kg}^{-1} \cdot \mathrm{d}^{-1}\right)$ & 0 & 31.5 \\
& & \\
Total volume $\left(\mathrm{ml} \cdot \mathrm{kg}^{-1} \cdot \mathrm{d}^{-1}\right)$ & 185 & 185 \\
\hline
\end{tabular}

* USV Laboratories, Tuckahoe, NY.

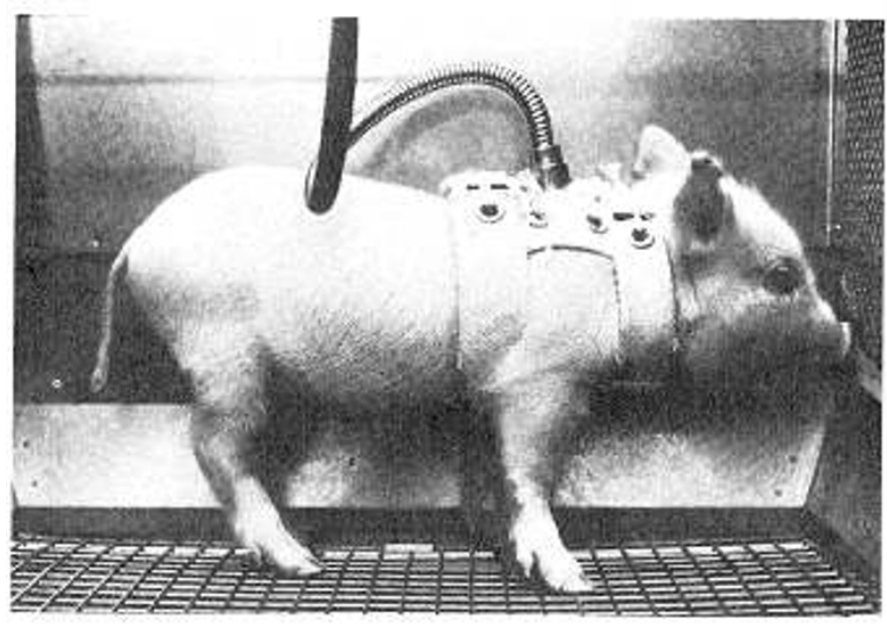

Fig. 1. The harness/tether assembly permitted the animal to move freely in the cage.

10-20 min later by pentobarbital sodium $(10 \mathrm{mg} / \mathrm{kg}$ intraperitoneally). Additional doses of pentobarbital $(5 \mathrm{mg} / \mathrm{kg})$ were given as needed to maintain anesthesia. Using aseptic technique, both external jugular veins were exposed and a 20-gauge silicone catheter was inserted into each of the vessels. The catheter in the left external jugular vein was passed to the level of the superior vena cava and the right external jugular vein catheter was passed into the right atrium. The positions of the catheters were confirmed using fluoroscopy. The catheters were tunneled subcutaneously and exited dorsally between the shoulders. A harness of our own design, which could be adjusted for size while on the pigs and which held the tether securely in place, was fitted to the animals. A standard tether and swivel were attached (Alice King Chatham Medical Arts, Los Angeles, CA). The harness/tether/ swivel assembly allowed the animal to move freely about the cage (Fig. 1). The pigs were wrapped in blankets to maintain body temperature and allowed to recover from the anesthesia. The TPN infusions were begun and administered continuously using constant infusion pumps (IMED Corporation, San Diego, $\mathrm{CA}$ and Abbott Laboratories, North Chicago, IL). Group A pigs received glucose/amino acids through both catheters; the rate of delivery in the left jugular line was $2 \mathrm{ml} / \mathrm{h}$ so that interruption for blood drawing would have a minimal effect on biochemical 
studies. In group B the Intralipid was delivered through the left jugular line.

Blood collections. Interruption of the infusion for blood withdrawal was usually no longer than $2 \mathrm{~min}$. The procedure was carried out aseptically. The dead space of the catheter was filled with sodium heparin $(1000 \mathrm{IU} / \mathrm{ml})$ which was withdrawn quantitatively and discarded before blood collection. Six milliliters of blood was drawn for serum chemistries, insulin, and cortisol measurements; a further $1 \mathrm{ml}$ was discharged into $500 \mathrm{U}$ Trasylol (FBA Pharmaceuticals Inc., New York, NY) and $1.2 \mathrm{mg}$ $\mathrm{Na}_{2}$ EDTA for glucagon determination; two 1-ml samples were collected using potassium oxalate and $\mathrm{Na}_{2}$ EDTA anticoagulants for glucose determination and a CBC respectively. Except for the $\mathrm{CBC}$ and glucose specimens, samples were placed in chilled glass tubes and centrifuged at $4^{\circ} \mathrm{C}$. The separated aliquots of plasma or serum were stored at $-20^{\circ} \mathrm{C}$ until analyzed. Glucose and $\mathrm{CBC}$ were measured on the day of collection.

Hormone analyses. Insulin was analyzed using a double antibody radioimmunoassay derived from the technqiues of Hales and Randle (15) and Morgan and Lazarow (23). Cortisol was determined with a solid-phase radioimmunoassay (Coat-aCount, Diagnostic Products Corp., Los Angeles, CA). The measurement of glucagon was made using standard radioimmunoassay employing the $30 \mathrm{~K}$ anti-pork glucagon antibody obtained from Dr. R. Unger (University of Texas, Dallas, TX).

Serum chemistries. A clinical chemistry Ektachem 400 autoanalyzer (Kodak Co., Rochester, NY) was used to determine $\mathrm{Na}, \mathrm{K}, \mathrm{Cl}$, and bicarbonate $\left(\mathrm{CO}_{2}\right)$ levels (with ion-sensitive electrodes), glucose (glucose oxidase-peroxidase method), total bilirubin [the method of Jendrassik and Grof (19)], urea (an indirect urease assay), and calcium (colorimetric determination with an arsenazo-III dye). Magnesium and phosphate were measured with a Dupont ACA analyzer (Dupont Co., Wilmington, DE); a complexometric assay with EGTA and methyl-thymol blue was used to determine magnesium, whereas phosphorus was measured by the Fiske and Subbarow method (13). A Cobas BI0 Centrifugal Analyzer (Roche Analytical, Nutley, NJ) was employed for albumin (bromo-cresol green dye-binding technique), total protein (Biuret reagent assay), and SGPT (LDH$\mathrm{NADH}$ system analysis) measuremnts. The $\mathrm{CBC}$ analyses which were carried out on a Coulter Counter (Coulter Co., Miami, FL) included a white blood cell count with differential, red blood cell count, hemoglobin, hematocrit, mean red cell volume, and platelet count.

Urinalysis. Urine, collected in a tray below each cage, was checked daily for $\mathrm{pH}$, glucose, ketones, blood, and protein with Labstix (Ames Co., Elkhart, IN).

Total body water. Each pig received $25 \mu \mathrm{Ci} / \mathrm{kg}$ of tritiated water (New England Nuclear Co., Boston, MA; specific activity, $50 \mu \mathrm{Ci} / \mathrm{ml}$ ) as a single bolus through the right jugular catheter; infusion of the TPN solution was continued immediately after, ensuring complete administration of the dose. Serial blood sampling for plasma activity determinations and subsequent calculation of tritium space was carried out as described by Udekwu et al. (34).

Whole body composition. The pig carcasses were analyzed for fat, nitrogen, ash, $\mathrm{Na}, \mathrm{K}$, and $\mathrm{Ca}$ as described by Sheng et al. (29), except that $\mathrm{Na}$ and $\mathrm{K}$ were measured by flame photometry. Whole body chloride was measured on dilute acid extracts $(0.75$ $\mathrm{N} \mathrm{HNO}_{3}$ ) of fat-free dried samples with a Buchler-Cotlove chloridometer. Phosphorus was determined by the Fiske and Subbarow technique (13) in the same concentrated acid digest $(\mathrm{HCl}$ and $\mathrm{HNO}_{3}$ ) prepared for the other mineral analyses.

\section{RESULTS}

There were no significant differences between groups in the mean weight of the pigs when TPN was begun or in the mean weight gain during the study (Table 2). The animals tolerated the intravenous nutriton without ill effects as indicated by both clinical and biochemical parameters.

Serum chemistries for each pig did not change significantly between $\mathrm{d} 2$ and $\mathrm{d} 8$ after initiation of TPN, and all values were in the normal range for minipigs $(11,27,32,33)$. Values for $d 8$ are shown in Table 3 . There also were no significant differences between groups except for blood urea nitrogen where Group B had a significantly higher value than Group A $(P<0.05)$.

Results of hormone determinations are given in Table 4 . There was a significant difference in insulin levels and in the insulin/ glucagon ratio between the two groups by $\mathrm{d} 8$. Group $\mathrm{A}$ had significantly higher levels of insulin $(P<0.05)$ as well as a higher insulin/glucagon ratio $(P<0.02)$ compared with Group B. Cortisol concentrations were not different between groups.

TBW (Table 5) was significantly greater in Group A compared with Group B $(P<0.01)$. No significant differences in fat, nitrogen, or ash per fat-free dry weight were observed (Table 5).

Total body $\mathrm{K}, \mathrm{Na}, \mathrm{Cl}, \mathrm{Ca}$, and $\mathrm{P}$ were not significantly different between groups. Extracellular space, calculated from body $\mathrm{Cl}$ and plasma $\mathrm{Cl}(9)$, was found to be similar between groups. A small but significant difference was observed in the Ca:P ratio, $1.16 \pm 0.01(\mathrm{SD})$ for group $\mathrm{A}$ and $1.20 \pm 0.01$ for group $\mathrm{B}(P<$ $0.05)$.

\section{DISCUSSION}

At the conclusion of the present study, the body composition of the infant miniature pigs corresponded to that of similar age pigs fed mother's milk, except for the amount of fat. Previous studies in various species of growing animals have shown that the nitrogen and bone composition of the body is relatively unaffected by increases in energy intake above standard requirements, whereas the amount of body fat is responsive to changes in energy and nitrogen intake $(5,10)$. If energy intake is held constant and nitrogen intake is increased, the amount of body fat decreases $(5,10)$. Conversely, if energy intake is increased, fat

Table 3. Serum characteristics on $d 8$ (mean $\pm S D$ )

\begin{tabular}{lccc}
\hline & $\begin{array}{c}\text { Group A } \\
(n=10)\end{array}$ & $\begin{array}{c}\text { Group B } \\
(n=8)\end{array}$ & Normals* \\
\hline Hemoglobin (g/dl) & $8.5 \pm 1.1 \dagger$ & $8.3 \pm 1.3 \dagger$ & $12.3 \pm 1.0$ \\
BUN (mg/dl) & $16.7 \pm 3.3$ & $19.9 \pm 3.0$ & 17.0 \\
Glucose (mg/dl) & $95.6 \pm 19.2$ & $94.3 \pm 10.9$ & $94.3 \pm 10.9$ \\
Albumin (g/dl) & $2.6 \pm 0.3$ & $2.7 \pm 0.2$ & $2.7 \pm 0.2$ \\
Protein (g/dl) & $4.8 \pm 0.4$ & $5.0 \pm 0.4$ & 4.8 \\
$\mathrm{Na}(\mathrm{mmol} / \mathrm{L})$ & $139.9 \pm 4.2$ & $140.1 \pm 4.0$ & 140 \\
$\mathrm{~K}(\mathrm{mmol} / \mathrm{L})$ & $4.4 \pm 0.4$ & $4.4 \pm 0.4$ & 3.9 \\
$\mathrm{Cl}(\mathrm{mmol} / \mathrm{L})$ & $98.3 \pm 4.0$ & $99.2 \pm 2.5$ & $93-108$ \\
$\mathrm{CO}(\mathrm{mEq} / \mathrm{L})$ & $24.8 \pm 4.7$ & $25.1 \pm 5.0$ & $26-31$ \\
$\mathrm{Ca}(\mathrm{mg} / \mathrm{dl})$ & $10.0 \pm 0.5$ & $9.6 \pm 0.4$ & 10.0 \\
$\mathrm{PO}(\mathrm{mg} / \mathrm{dl})$ & $6.1 \pm 1.2$ & $5.5 \pm 0.9$ & $5.3 \pm 9.6$ \\
$\mathrm{Mg}(\mathrm{mg} / \mathrm{dl})$ & $2.2 \pm 0.2$ & $2.1 \pm 0.2$ & $1.8 \pm 2.6$ \\
$\mathrm{SGPT}(\mathrm{IU} / \mathrm{L})$ & $16.1 \pm 4.8$ & $17.4 \pm 6.2$ & $19-31$ \\
$\mathrm{Bilirubin}(\mathrm{mg} / \mathrm{dl})$ & $0.2 \pm 0.0$ & $0.4 \pm 0.5$ & $0.9 \pm 0.1$ \\
\hline
\end{tabular}

* Reference numbers $(27,33,32,11)$.

$\uparrow$ Reduced values due to the streaming effects of drawing blood through the small bore, $1.5 \mathrm{~m}$ catheters.

Table 2. Age, weight gain, and energy intake (mean $\pm S D)$

\begin{tabular}{lcccc}
\hline Group & $\begin{array}{c}\text { Age } \\
(\mathrm{d})\end{array}$ & $\begin{array}{c}\text { Weight } \\
(\mathrm{kg})\end{array}$ & $\begin{array}{c}\text { Weight gain } \\
\left(\mathrm{g} \cdot \mathrm{kg}^{-1} \cdot \mathrm{d}^{-1}\right)\end{array}$ & $\begin{array}{c}\text { Energy intake } \\
\left(\mathrm{kcal} \cdot \mathrm{kg}^{-1} \cdot \mathrm{d}^{-1}\right)\end{array}$ \\
\hline $\mathrm{A}(n=10)$ & $10.4 \pm 3.2$ & $1.82 \pm 0.33$ & $31.1 \pm 11.6$ & $170.6 \pm 1.5$ \\
$\mathrm{~B}(n=8)$ & $10.0 \pm 2.7$ & $1.67 \pm 0.29$ & $31.0 \pm 10.2$ & $171.6 \pm 1.6$ \\
\hline
\end{tabular}


Table 4. Serum hormones on $d 2$ and 8 (mean $\pm S D$ )

\begin{tabular}{lccccc}
\hline Group & \multicolumn{1}{c}{$\begin{array}{c}\text { Glucagon } \\
(\mathrm{pg} / \mathrm{ml})\end{array}$} & $\begin{array}{c}\text { Insulin } \\
(\mu \mathrm{U} / \mathrm{ml})\end{array}$ & Insulin/glucagon & $\begin{array}{c}\text { Cortisol } \\
(\mu \mathrm{g} / \mathrm{dl})\end{array}$ \\
\hline $\mathrm{A}(n=10)$ & 2 & $48.5 \pm 19.3$ & $188.5 \pm 95.5$ & $0.318 \pm 0.211$ & $2.5 \pm 2.4$ \\
$\mathrm{~A}$ & 8 & $54.5 \pm 24.5^{*}$ & $154.7 \pm 125.7$ & $0.529 \pm 0.354 \dagger$ & $2.6 \pm 1.7$ \\
$\mathrm{~B}(n=8)$ & 2 & $37.0 \pm 11.4$ & $259.1 \pm 121.0$ & $0.165 \pm 0.073$ & $2.6 \pm 1.3$ \\
$\mathrm{~B}$ & 8 & $30.9 \pm 16.7^{*}$ & $239.1 \pm 137.4$ & $0.188 \pm 0.164 \dagger$ & $2.2 \pm 0.6$ \\
\hline$* P<0.05$ & & & & &
\end{tabular}

Table 5. Body composition results (mean $\pm S D$ )

\begin{tabular}{lccc}
\hline & $\begin{array}{c}\text { Group A } \\
(n=10)\end{array}$ & $\begin{array}{c}\text { Group B } \\
(n=8)\end{array}$ & Normals \\
\hline TBW (ml/g FFW)* & $0.845 \pm 0.026 \dagger$ & $0.797 \pm 0.025$ & $0.788 \ddagger$ \\
Fat (g/g FFD)§ & $0.356 \pm 0.136$ & $0.285 \pm 0.102$ & $0.630 \ddagger$ \\
$\mathrm{N}$ (g) & $45.4 \pm 11.1$ & $41.9 \pm 7.7$ & $45.0 \|$ \\
$\mathrm{N}(\mathrm{g} / \mathrm{g} \mathrm{FFD})$ & $0.121 \pm 0.005$ & $0.117 \pm 0.006$ & $0.120 \|$ \\
$\mathrm{Ash}$ (g/g FFD) & $0.156 \pm 0.010$ & $0.148 \pm 0.016$ & $0.158 \ddagger \|$ \\
$\mathrm{Cl}(\mathrm{mmol} / \mathrm{g}$ FFD) & $0.198 \pm 0.024$ & $0.196 \pm 0.023$ & $\ldots$ \\
$\mathrm{Na}(\mathrm{mmol} / \mathrm{g}$ FFD) & $0.352 \pm 0.030$ & $0.329 \pm 0.029$ & $0.322 \|$ \\
$\mathrm{K}$ (mmol/g FFD) & $0.329 \pm 0.038$ & $0.298 \pm 0.016$ & $0.317 \|$ \\
$\mathrm{Ca}(\mathrm{mmol} / \mathrm{g}$ FFD) & $1.031 \pm 0.069$ & $1.020 \pm 0.132$ & $1.125 \|$ \\
$\mathrm{P}$ (mmol/g FFD) & $0.888 \pm 0.054$ & $0.849 \pm 0.095$ & $0.974 \|$ \\
\hline
\end{tabular}

${ }^{*} \mathrm{FFW}$, fat-free wet weight.

$\dagger \mathrm{P}<0.01$.

$\ddagger$ Orally fed (unpublished data), TBW measured by dessication.

$\S$ FFD, fat-free dry weight.

\| Orally fed, eviscerated $(8,37)$, whole body $(35)$.

deposition will increase $(5,10)$. The nitrogen intake of the pigs in the present study met the recommended allowances for swine, however, the energy intakes were at the lower end of the recommendations $(25,27)$. Thus, the adequate nitrogen but low energy intakes explain the finding of reduced body fat in these study animals compared with orally fed pigs. The energy intake of the animals was based upon recommended allowances and the experience of Pfrimmer et al. (26), Badger et al. (3), and Tumbelson (personal communication, 1981). Higher energy intakes will be necessary in future studies if greater fat accretion is desired.

In view of the different hormone profiles in the two groups, differences in nitrogen retention and body composition might have been anticipated. Insulin causes lipogenesis, amino acid uptake into muscle, and stimulates protein synthesis $(2,7)$. Glucagon, on the other hand, induces lipolysis, amino acid movement into viscera, and gluconeogenesis $(2,7)$. The higher blood urea nitrogen in Group B probably reflected the effect of glucagon which is known to stimulate urea formation as a consequence of gluconeogenesis (2). It has been suggested that the higher insulin level stimulated by a glucose/amino acid fuel mix will result in greater nitrogen retention compared with a mix which includes fat (20). This was postulated by Long et al. (20) who found that nitrogen retention improved with increasing carbohydrate intake in critically ill adult patients; addition of intravenous fat did not affect nitrogen retention. In contrast, oral feeding studies carried out in growing animals have shown that carbohydrate and fat have equal ability to promote nitrogen retention within a few days of substituting one substrate for the other (24). TPN studies in adults $(4,18)$, children $(28)$, and rats (31) substantiate the oral feeding studies. Discrepancies betwen the results of these studies and those of Long and co-workers may be explained, in part, by differences in the clinical status of the patients; those in Long's study were critically ill as compared with patients in the studies cited above $(4,18,28)$.

If nitrogen retention is not affected by the fuel mix, might other components of body composition be altered? Studies by
Macfie et al. (22) in malnourished adults, using neutron activation analysis to measure body nitrogen, have suggested that a glucose/amino acid fuel mix induces fat and water retention in excess of expected gains in nitrogen. As was found in the present study, TBW was greater in those patients who received glucose/ amino acids compared with those who also were given fat $(22)$. An explanation for these differencs in TBW may be the higher insulin levels in the glucose/amino acid group. Insulin promotes glycogen formation, the deposition of which is associated with an obligatory amount of water [approximatley $4 \mathrm{~g}$ of water per gram of glycogen (8)]; thus, the larger TBW may have represented greater glycogen deposition (8). The finding of increased intracellular water, as measured by the difference between $\left[{ }^{3} \mathrm{H}_{2} \mathrm{O}\right]$ and chloride spaces, would support this hypothesis.

No differences in body fat were found between groups in the present investigation in contrast to the study by Macfie et al. (22). The subjects in the latter study, however, were malnourished, ill, adult humans whereas the pigs in the present investigation were young and healthy. Differences in the relative adequacy of energy intakes also could account for the discrepancy. Additionally, Macfie and coworkers measured body fat using less accurate, indirect methods.

In a study by Hartsook and Hershberger (16) of orally fed rats, alteration of the carbohydrate/fat ratio had no significant effect on whole body, ash, nitrogen, and fat at levels of protein intake comparable to those administered in this study. It would appear that the factors which ultimately control the composition of growth can override the effects of insulin and glucagon. Although plasma levels of the hormones may be increased or decreased, tissue sensitivity may be altered such that normal body composition is maintained. That changes in hormone-tissue relationships occur, is supported by the work of Byrne et al. (6) who found decreases in insulin binding as a result of the hyperinsulinemia induced by a TPN fuel mix similar to that used in group A. It would appear that the growing animal has the ability to adapt to a wide range of carbohydrate/fat intakes. Further investigation is required however, to determine whether differences in the carcass and visceral distribution of nitrogen occur as a result of the fuel mix or whether the high glucose loads of the fuel mix given to animals in group A might induce a metabolic stress.

\section{REFERENCES AND NOTES}

1. Asch, M. J., Sperling, M., Fiser, R., Leake, R., Moore, T. C., and Oh, W.: Metabolic and hormonal studies comparing three parenteral nutrition regimens in infants. Ann. Surg., 182: 62 (1975).

2. Alberti, K. G. M. M.: Metabolic pathways-hormone metabolic interrelations. In: S. J. Karran and K. G. M. M. Alberti: Practical Nutritional Support. p. 5 (John Wiley and Sons, New York, 1980).

3. Badger, T. M., Wixom, R. L., Gerhardt, K. O., Gehrke, C. W., and Terry, B. E.: Total parenteral nutrition in the miniature swine: essential fatty acid deficiency. J. Parent. Nutr., 2: 116 (1978).

4. Bark, S., Holm, I., Hakansson, I., and Wretlind, A.: Nitrogen sparing effect of fat emulsion compared with glucose in the post-operative period. Acta Chir. Scand., 142: 423 (1976).

5. Blaxter, K. L.: Energy utilization and obesity in domesticated animals. In: G. A. Bray: Obesity in Perspective, DHEW Publication No. (NIH) 75-708, 1973.

6. Byrne, W. J., Lippe, B. M., Stroebel, C. T. Levin, S. R., Ament, M. E., and Kaplan, S. A.: Adaptation to increasing loads of total parenteral nutrition: metabolic, endocrine and insulin receptor responses. Gastroenterology, 80 : 947 (1981). 
7. Carlo, P. E.: Hormonal control of substrate utilization in parenteral nutrition. In: J. M. Greep, P. B. Soeters, R. I. K. Wesdorp, C. W. R. Phaf, and J. E. Fischer: Current Concepts in Parenteral Nutrition. p. 39 (Martinus Nijhoff Medical Division, The Hague, 1977)

8. Chan, S. T. F., Johnson, A. W., Moore, M. H., Kapadia, C. R., and Dudley, H. A. F.: Early weight gain and glycogen-obligated water during nutritional rehabilitation. Hum. Nutr.: Clin. Nutr. 36C: 223 (1982).

9. Cheek, D. B., West, C. O., and Golden, C. C.: The distribution of sodium and chloride and the extracellular fluid volume in the rat. J. Clin. Invest., 37: 340 (1957)

10. Combs, G. F.: Nutrition and management aspects of nonruminant animals related to reduction of fat content in meat. In: Fat Content and Composition of Animal Products. p. 116 (National Academy of Sciences, Washington, D.C., 1976).

11. Earl, F. L., Melvegor, B. E., Reinwall, J. E., and Wilson, R. L.: Clinical laboratory values of neonatal and weanling miniature pigs. Lab. Anim. Sci., 21: 754 (1971).

12. Filer, L. J., Fomon, S. J., Anderson, T. A., Andersen, D. W., Rogers, R. R., and Jensen, R. L.: Effect of age, sex, and diet on growth, serum chemical values, and carcass composition of Pitman-Moore miniature pigs during the first four weeks of life. Growth, 38: 197 (1974).

13. Fiske, C. H. and Subbarow, Y.: The colorimetric determination of phosphorus. J. Biol. Chem., 66: 375 (1925).

14. Gazzaniga, A. B., Bartlett, R. H., and Shobe, J. B.: Nitrogen balance in patients receiving either fat or carbohydrate for total intravenous nutrition. Ann. Surg., 182: 163 (1975).

15. Hales, C. N. and Randle, P. J.: Immunoassay of insulin with insulin-antibody precipitate. Biochem. J., 88: 137 (1963).

16. Hartsook, E. W. and Hershberger, T. V.: Interactions of major nutrients in whole animal energy metabolism. Fed. Proc., 30: 1466 (1971).

17. JeeJeebhoy, K. N.: Relationship of energy and protein input to nitrogen retention and substrate hormone profile. In: J. M. Greer, P. B. Soeters R. C. Wesdorp, C. W. R. Phaf, and J. E. Fischer: Current Concepts in Parenteral Nutrition. p. 313 (Martinus Nijhoff Medical Division, The Hague, 1977).

18. JeeJeebhoy, K. N., Anderson, G. H., Nakhodda, A. F., Greenberg, G. R., Sanderson, I., and Marliss, E. B.: Metabolic studies in total parenteral nutrition with lipid in man. J. Clin. Invest., 57: 125 (1976).

19. Jendrassik, L. and Grof, P.: Simplified photometric methods for the determination of the blood bilirubin. Biochem. Z. 297: 81 (1938).

20. Long, J. M., Wilmore, D. W., Mason, A. D., and Pruitt, B. A.: Effect of carbohydrate and fat intake on nitrogen excretion during total intravenous feeding. Ann. Surg., 185: 417 (1977).

21. Levy, J. S., Winters, R. W., and Heird, W. C.: Total parenteral nutrition in pediatric patients. Pediatr. Rev., 2: 99 (1980).

22. Macfie, J., Smith, R. C., and Hill, G. L.: Glucose or fat as a non-protein energy source? Gastroenterology, 80: 103 (1981).

23. Morgan, C. R. and Lazarow, A.: Immunoassay of insulin: two antibody system. Diabetes, 12: 115 (1963).

24. Munro, H. N.: General aspects of the regulation of protein metabolism by diet and by hormones. In: H. N. Munro and J. B. Allison: Mammalian Protein Metabolism. Vol. I p. 381 (Academic Press, New York, 1964).

25. National Academy of Sciences: Nutrient Requirements of Swine. In: Nutrient Requirements of Domestic animals. p. 2 (National Academy of Sciences, Washington, D. C., 1979).

26. Pfrimmer, W., Pemsel, W., Berg, G., Schwille, P., and Bergner, D.: Methodische and technische Probleme der langfristigen Infusionstherapie mit dem CavaKatheter. Z. Ernaehrungswiss., 11: 254 (1972).

27. Pond, W. G. and Houpt, K. A.: The Biology of the Pig. (Cornell University Press, Ithaca, 1978).

28. Rubecz, I., Mestyan, J., Varga, P., and Klujber, L.: Energy metabolism, substrate utilization and nitrogen balance in parenterally fed post-operative neonates and infants. J. Pediatr., 98: 42 (1981).

29. Sheng, H. P., Huggins, R. A. and Garza, C.: Chemical maturation in growing guinea pigs. Am. J. Physiol., 242: R390 (1982)

30. Shenken, A. and Wretlind, A: Parenteral nutrition. World Rev. Nutr. Diet. 28: 1 (1978).

31. Stein, T. P., Buzby, G. P., Leskiw, M. J., Giandomenico, A. R., and Mullen, J. L.: Protein and fat mtabolism in rats during repletion with total parenteral nutrition. J. Nutr., 111: 154 (1981).

32. Tumbelson, M. E., Hicklin, K. W., and Burns, M. F.: Serum cholesterol, triglyceride, glucose and total bilirubin concentrations as functions of age and sex in Sinclair miniature swine. Growth, 40: 293 (1976).

33. Tumbelson, M. E., Hutcheson, D. P., and Middleton, C. C.: Serum protein concentrations and enzyme activities as functions of age and sex in Sinclair miniature swine. Growth, 40:53 (1976).

34. Udekwu, F. A. O., Kozoll, D. D., and Meyer, K. A.: Determination of total body water with tritium oxide. J. Nucl. Med., 4: 60 (1963).

35. Wood, A. J. and Groves, T. D. D.: Body composition studies on the suckling pig. Can. J. Anim. Sci., 45: 8 (1965).

36. The authors gratefully acknowledge the technical assistance of Dorothy $J$. Barber, Gail Harrison, Mark Junker, R.Ph., Lavonne Cox Woznicki, R.Ph., and Nancy F. Butte, Ph.D.; editorial review by E. R. Klein; manuscript preparation by C. Blackshire and M. E. Boyd; and the generosity of Cutter Medical, Travenol Laboratories, and Abbott Laboratories. Special thanks to Dr. J. Rosborough for his invaluable help.

37. Requests for reprints should be addressed to: Dr. Robert J. Shulman, Section of Nutrition and Gastroenterology, Texas Children's Hospital, 6621 Fannin St., Houston, TX 77030.

38. Received for publication June 13, 1983.

39. Accepted for publication September 29, 1983. 